\title{
THE VERTEBRATE FAUNA RECORDED FROM NORTHEASTERN SINAI, EGYPT
}

\author{
Soliman, Sohail ${ }^{1}$ and Eman M.E. Mohallal ${ }^{2 *}$ \\ ${ }^{1}$ Department of Zoology, Faculty of Science, Ain Shams University, \\ El-Abbaseya, Cairo, Egypt \\ ${ }^{2}$ Department of Animal and Poultry Physiology, Desert Research \\ Center, El Matareya, Cairo, Egypt \\ *E-mail: emanmohallal@yahoo.com
}

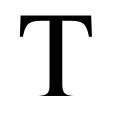

he vertebrate fauna was surveyed in ten major localities of northeastern Sinai over a period of 18 months (From September 2003 to February 2005, inclusive). A total of 27 species of reptiles, birds and mammals were recorded. Reptiles are represented by five species of lizards: Savigny's Agama, Trapelus savignii; Nidua Lizard, Acanthodactylus scutellatus; the Sandfish, Scincus scincus; the Desert Monitor, Varanus griseus; and the Common Chamaeleon, Chamaeleo chamaeleon and one species of vipers: the Sand Viper, Cerastes vipera. Six species of birds were identified during casual field observations: The Common Kestrel, Falco tinnunculus; Pied Avocet, Recurvirostra avocetta; Kentish Plover, Charadrius alexandrines; Slender-billed Gull, Larus genei; Little Owl, Athene noctua and Southern Grey Shrike, Lanius meridionalis. Mammals are represented by 15 species; Eleven rodent species and subspecies: Flower's Gerbil, Gerbillus floweri; Lesser Gerbil, G. gerbillus, Aderson's Gerbil, G. andersoni (represented by two subspecies), Wagner's Dipodil, Dipodillus dasyurus; Pigmy Dipodil, Dipodillus henleyi; Sundevall's Jird, Meriones crassus; Negev Jird, Meriones sacramenti; Tristram's Jird, Meriones tristrami; Fat Sand-rat, Psammomys obesus; House Mouse, Mus musculus and Lesser Jerboa, Jaculus jaculus. Three carnivores: Red Fox, Vulpes vulpes; Marbled Polecat, Vormela peregosna and Common Badger, Meles meles and one gazelle: Arabian Gazelle, Gazella gazella.

Keywords: reptiles, birds, mammals, north Sinai, Egypt.

In recent years, the wild vertebrate fauna of Egypt became threatened by a variety of human activities; such as the expanding human population, direct hunting, ecotourism, industrial and agricultural development and urbanization (Hoath, 2003). These activities may result in 
disappearance of local species or introduction of alien ones. Regular surveys of vertebrates are thus needed to evaluate the effect of such human activities, and to update different lists of reptiles, birds and mammals of different natural habitats of Egypt. Updated lists of extant species are important for wildlife conservationists, public health authorities, and vertebrate pest managers. The present survey was carried out during a study of the population ecology, and taxonomy of rodents of the area.

\section{MATERIALS AND METHODS}

\section{The Study Area}

The present work was carried out in northeastern Sinai Peninsula (Table 1 and Fig. 1). Generally, this part of Sinai has a low elevation, and consists of wide plains, which slope gradually northwards. It is covered with sparsely vegetated sand. Eolian sand dunes with elevations of 80-100 meters are common throughout the area. The Bardawil Lake, a shallow saline lake enclosed by an offshore bar, occupies the central sector of this region. The area receives plentiful winter rains, which are absorbed by sand dunes, thus forming permanent source of water in the low lands between these dunes that can be trapped by digging wells (Abu Al-Izz, 1971). During the study period, the annual amount of rainfall ranged between $108 \mathrm{~mm}$ (winter 2003/2004) and $273 \mathrm{~mm}$ (winter 2004/2005). Monthly average air temperature ranged between $13^{\circ} \mathrm{C}$ (January 2005) and $26^{\circ} \mathrm{C}$ (August 2004), while the monthly average relative humidity ranged between $79.5 \%$ (January 2004 and 2005) and 94\% (July 2004).

Table (1). Major collection localities and field observation sites of the vertebrate fauna of northeastern Sinai.

\begin{tabular}{lcc}
\hline Locality & N lat. & E long. \\
\hline - Al-Arish & $31^{\circ} 07^{\prime}$ & $33^{\circ} 25^{\prime}$ \\
1. Al-Zaranik & $31^{\circ} 07^{\prime}$ & $33^{\circ} 49^{\prime}$ \\
2. Abu Egerem & $31^{\circ} 08^{\prime}$ & $33^{\circ} 54^{\prime}$ \\
3. Bir Lehfen and Al-Quore'aa & $31^{\circ} 00^{\prime}$ & $33^{\circ} 52^{\prime}$ \\
4. Al-Kharafeen & $31^{\circ} 11^{\prime}$ & $34^{\circ} 10^{\prime}$ \\
5. Al-Dhahir & $31^{\circ} 11^{\prime}$ & $34^{\circ} 08^{\prime}$ \\
6. Al-Gora & $31^{\circ} 04^{\prime}$ & $34^{\circ} 08^{\prime}$ \\
7. Wadi El-Agra & $31^{\circ} 03^{\prime}$ & $34^{\circ} 17^{\prime}$ \\
8. Sadd El-Raawaf'aa area & $30^{\circ} 50^{\prime}$ & $34^{\circ} 08^{\prime}$ \\
9. Wadi Umm Shehan & $30^{\circ} 47^{\prime}$ & $34^{\circ} 11^{\prime}$ \\
\hline
\end{tabular}

Egyptian J. Desert Res., 66, No. 1, 35-55 (2016) 


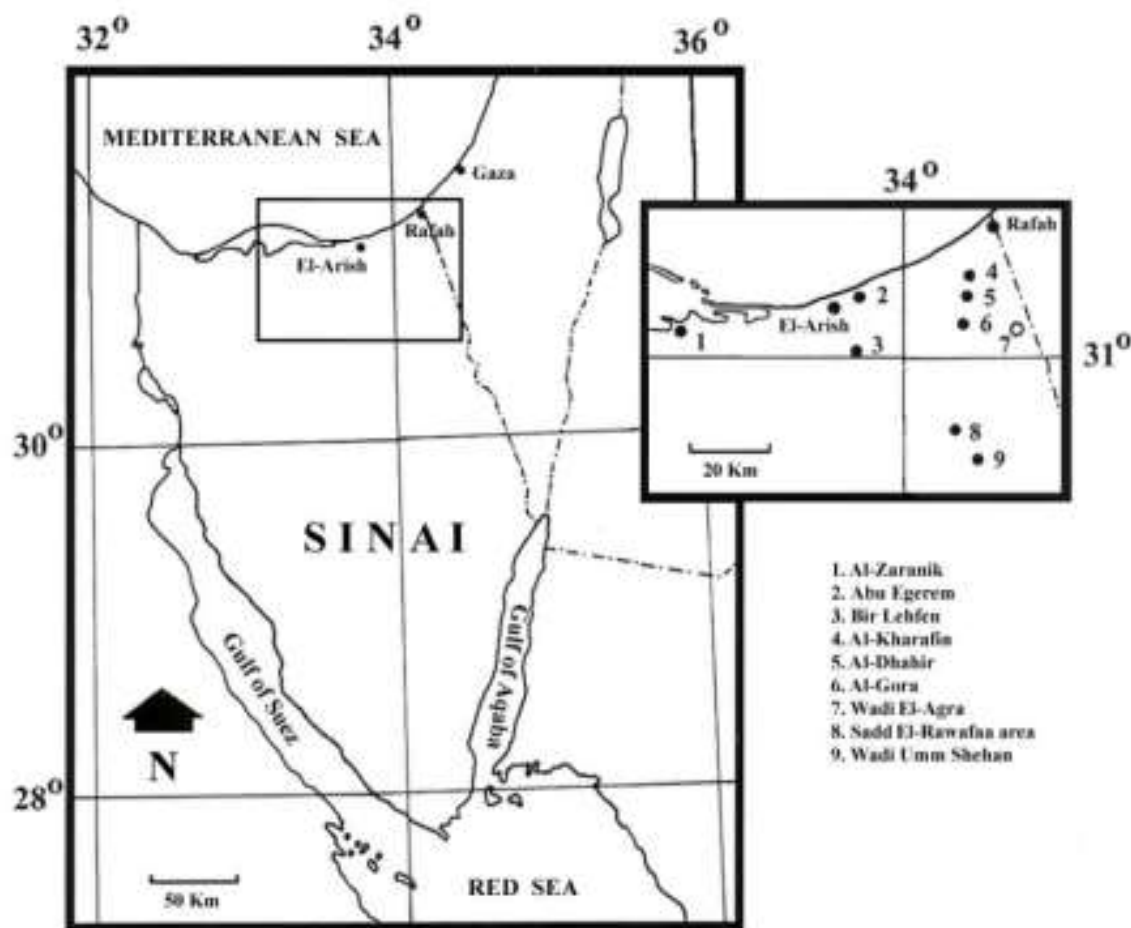

Fig. (1). Collection localities and field observation sites of the vertebrate fauna of northeastern Sinai.

\section{Survey of Vertebrate Species}

Monthly trapping of rodent specimens continued for 18 months extending from September 2003 till February 2005, inclusive. The traps were baited with bread and set shortly before sunset in areas of rodent activity as indicated by their foot tracks and burrow openings. The traps were checked early in the next morning and the captured rodents were transported to the laboratory in Al-Arish. Live specimens were euthanized with an overdose of ether and all specimens were given a catalogue number, sexed, weighed to the nearest $0.1 \mathrm{~g}$. The survey of other mammalian groups, birds and reptiles was based on field observations and/or specimens delivered by local Bedouins. The keys and descriptions provided by Baha El Din (2006) for reptiles, descriptions of Tharwat (1997), and Porter and Cottridge (2001) for birds, and keys and measurements provided by Osborn and Helmy (1980) for mammals, were used for the identification of collected and/or observed specimens. 


\section{RESULTS AND DISCUSSION}

A total of 27 species of reptiles, birds and mammals were recorded. Reptiles are represented by five species of lizards and one species of vipers. Six species of birds were identified and mammals are represented by 15 species; eleven rodent species and subspecies, three carnivores and one gazelle.

\section{Class: Reptilia \\ Order: Squamata \\ Suborder: Sauria}

1.1. Family: Agamidae

Trapelus savignii (Dumeril and Bibron, 1837)

\section{Savigny's Agama}

It is known from a sight record of a male, with a blue throat, in Wadi

El-Agra area (Fig. 2). The blue throat and violet-blue flanks in males is a sign of a breeding condition (Baha El Din, 2006). The distribution of this lizard covers the northern part of the Eastern Desert and throughout much of northern Sinai, to the eastern borders of Egypt. It was recorded in the area between Ismailia and Suez (Anderson, 1898), and El-Arish (Saleh, 1997). The species is particularly endemic to Egypt with most of its world range lying within the country (Baha El Din, 2006). It inhabits sandy areas, vegetated sand dunes, sand sheets, gravel plains, and areas of fine alluvium in large wadis. However, it generally prefers areas with good vegetation cover (Saleh, 1997 and Baha El Din, 2006). The same authors added that it often climbs on the top of vegetation to watch for prey, and for thermoregulatory purposes. The animal suffers from extensive habitat loss and overcollection for pet trade (Baha El Din, 2006).

\subsection{Family: Lacertidae \\ Acanthodactylus scutellatus (Audouin, 1829) Nidua Lizard}

It is known from a sight record in Wadi El-Agra area (Fig. 3). Its distribution covers the Western and Eastern Deserts, and Sinai where it is confined to the northern part of the Peninsula, but extends southwards along the coastal plain of the Gulf of Suez (Baha El Din, 2006). It was collected from Ain Musa and Suez district (Anderson, 1898), South Sinai (St. Catherine Monastery area), Gebel Elba region, Qalubiya, Beheira (Wadi ElNatroun), Cairo, Giza, El Faiyum, Minya, Aswan, and Matruh Governorates (Marx, 1968). It is a typical lizard of open sandy areas, where it is found in sand plains, sand dunes, sandy wadis with modest vegetation cover, and sometimes in areas with very little vegetation (Saleh, 1997 and Baha El Din, 2006). It is entirely diurnal, but tends to be more restricted to the early morning and late afternoon during summer, and mid-day during winter, 
however, it can tolerate extreme desert conditions (Baha El Din, 2006). It feeds on small insects particularly ants (Saleh, 1997).

\subsection{Family: Scincidae \\ Scincus scincus (Linnaeus, 1758) \\ Sandfish}

It is only known from its diagnostic tracks in Wadi El-Agra area in a site of soft sand (Fig. 4). The distribution of this species covers northern and central Sinai, Northern Eastern Desert, sandy areas of the Western Desert including Northern Qattara Depression (Saleh, 1997 and Baha El Din, 2006). It was collected from the sand desert of the Pyramids of Giza, and Bahariya Oasis as recorded by Anderson (1898). He added that it was not found in Lower Egypt, and it was rare in Upper Egypt. Marx (1968), however, collected this species from Matruh (Burg El-Arab), Sharqiya, Minufiya, Beheira (Wadi El-Natroun), Giza, El Faiyum, Beni Suef, and Asyut Governorates. It inhabits areas of sand and sand dunes with modest vegetation cover, but it is often found in completely barren localities; such as in the Great Sand Sea (Baha El Din, 2006). It lives mostly under the sand, and runs on the sand surface at night (Saleh, 1997).

\subsection{Family: Varanidae \\ Varanus griseus (Daudin, 1803) \\ Desert Monitor}

It is known from a sight record in Wadi El-Agra area (Fig. 5), and from foot and tail prints in Zaranik Protectorate (Fig. 6). The distribution of the species covers the Western and Eastern Deserts and northern Sinai. It was collected from Suez, the desert located northeast of Cairo (Anderson, 1898), Matruh, Beheira, Sharqiya, Giza, El Faiyum, and Minya Governorates, and Gebel Elba region in southeastern most part of Egypt (Marx, 1968). It inhabits sandy areas; such as desert plains and large wadis with some vegetation cover (Saleh, 1997), however it prefers areas with fairly good vegetation (Baha El Din, 2006). It is a large diurnal carnivorous lizard, which feeds on lizards, snakes and rodents. It can ingest an Egyptian Dabb lizard, Uromastyx aegyptius, with a comparable body size. During its foraging activity, it covers very large areas. Its home range may be as large as $5 \mathrm{~km}^{2}$ in arid regions, where it travels distances of up to $8 \mathrm{~km}$ long (Bennett, 1995). According to Baha El Din (2006), large numbers of this lizard are collected for the pet trade and occasionally for leather. 


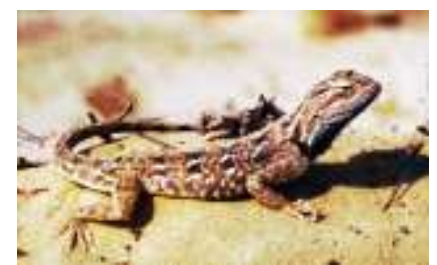

Fig. (2). Trapelus savignii
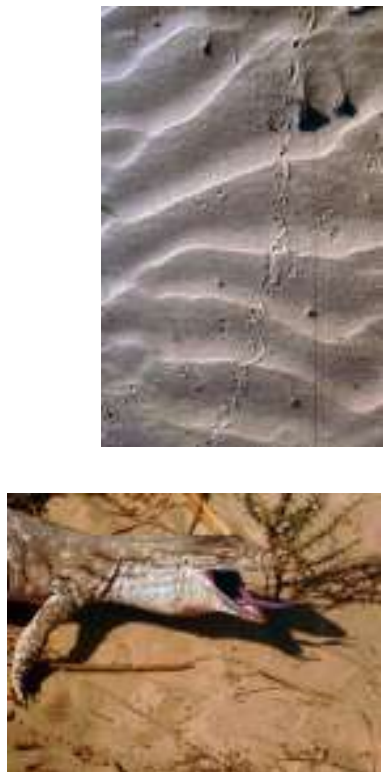

Fig. (5). Varanus griseus

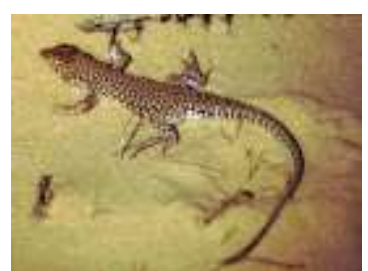

Fig. (3). Acanthodactylus scutellatus

Fig. (4). Tracks of Scincus scincus observed in Wadi El-Agra.

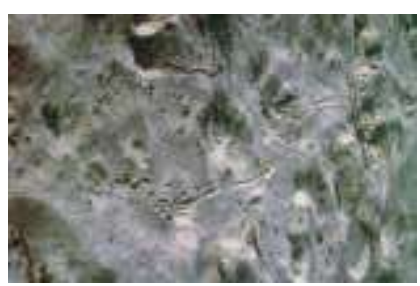

Fig. (6). Foot and tail prints of Varanus griseus observed in Zaranik Protectorate.

\subsection{Family: Chamaeleonidae \\ Chamaeleo chamaeleon (Linnaeus, 1758) \\ Common Chameleon}

It is known from a sight record of an individual chameleon climbing the branches of a desert bush in Wadi El-Agra area. Chameleons of Sinai are referred to the subspecies musae (Saleh, 1997 and Baha El Din, 2006), and are distributed in northern and central regions of the Peninsula. It was collected from Ain Musa (Anderson, 1898), Suez, Matruh, Alexandria, and Beheira (Wadi El-Natroun) Governorates (Marx, 1968), and Al-Arish (Saleh, 1997). It is only observed on the ground while moving from one bush to another. It is entirely diurnal and feeds on insects (Saleh, 1997). It is also found in dunes with scarce vegetation and sparsely vegetated wadis and plains as recorded by Baha El Din (2006). He added that it is common along the Mediterranean coast, particularly between El Arish and Rafah, and 
penetrates in small numbers into the desert along wadis like Wadi El-Arish and Wadi Hassana.

\section{Suborder: Serpentes \\ 1.6. Family: Viperidae \\ Viper Cerastes vipera (Linnaeus, 1758) \\ Sand Viper}

The characteristic tracks of a viper were observed on an area of soft sand in Wadi El-Agra area (Fig. 7). These tracks most probably belong to a sand viper since horned vipers, $C$. cerastes, are absent from the dune fields of northern Sinai (Baha El Din, 2006). According to the same author, $C$. vipera is common and widespread in the northern dune fields of Sinai, extending westward along the coastal plain of the Gulf of Suez. Its distribution also covers sandy deserts throughout most of Egypt, the Mediterranean coastal desert, and northern part of the Eastern Desert (Saleh, 1997 and Baha El Din, 2006). Anderson (1898) earlier indicated that this species was common on the margin of the desert around Cairo, and on the Isthmus of Suez, in Middle Egypt, and probably much further to the south. It was also collected from Suez, Matruh (El Maghra, Mersa Matruh, Sidi Barrani, and Siwa Oasis), Beheira (Wadi El-Natroun), Giza, El Faiyum and Minya Governorates (Marx, 1968). It strictly inhabits sandy habitats, particularly sand dune areas (Saleh, 1997). It is nocturnal and prefers lightly vegetated dunes (Baha El Din, 2006). It mostly feeds on lizards, rodents, and possibly birds (Saleh, 1997).

\section{Class:Aves}

\section{Order: Falconiformes}

2.1. Family: Falconidae

Falco tinnunculus (Linnaeus, 1758)

\section{Common Kestrel}

It is known from two captive specimens hold by local Bedouins, one in Wadi El-Agra area and the other in Al-Gora area (Fig. 8). Kestrels of Sinai belong to the subspecies Falco tinnunculus. It inhabits open land, cultivated fields, and rocky sea coasts. The nest is built in hollows of rocks, on ledges of buildings and on tree trunks, and often in abandoned nest of another bird (Tharwat, 1997). It is a common resident of Egypt. The distribution of this subspecies covers Nile Valley and Delta, Sinai, and northern Coast (Tharwat, 1997). In Sinai, it breeds at Al-Arish, and probably nests at St. Catherine, Sharm El Sheikh, and Wadi Taba (Goodman et al., 1989). It feeds on locusts, frogs, lizards, young chicken, larks, mice, and some carcasses (Meinertzhagen, 1930 and Anany, 2004). It flies at heights of about 50 meters in search of preys (Anany, 2004). 
Order: Chardriiformes

2.2. Family: Recurvirostridae

Recurvirostra avocetta (Linnaeus, 1758)

Pied Avocet

It is known from a sight record of five individuals in the wetlands of Zaranik Protectorate. It is a terrestrial bird that nests colonially in saline areas, however, it swims when occasionally meets deep water. It is known from Wadi EL Natroun, EL- Faiyum, Nile Delta, Idku district, lakes of Manzala and Burullus in northern Egypt, and lakes of Murrah and Temsah of Suez Canal area, and northern Sinai (Tharwat, 1997; Goodman et al., 1989 and Anany, 2004). It is a common winter, and a rare summer visitor (Meinertzhagen, 1930; Al-Husseini, 1954 and Tharwat, 1997), and can also be seen in spring and autumn migrations (Meinertzhagen, 1930 and Porter and Cottridge, 2001). During autumn migration, several thousand pass along the north coast of Sinai (Goodman et al., 1989). Anany (2004), however, concluded, on the basis of his own sight records, that this species is a permanent, though rare, resident of the country. Records of this species from the Western Desert (Siwa and Dakhla Oases) indicate a trans-Saharan migration (Goodman et al., 1989). They added that the avocet was irregularly recorded in small numbers along the Red Sea coast in autumn and spring.

\subsection{Family: Charadriidae}

Charadrius alexandrinus (Linnaeus, 1758)

\section{Kentish Plover}

It is known from a sight record of a single individual in the shallow waters of Zaranik Protectorate. It is one of the characteristic birds of the shorelines, which also inhabit expanses of sand and mud near water, and marshland. In Egypt, it is a fairly common breeding resident, particularly in the north, and a common passage migrant, and winter visitor (Al-Husseini, 1954; Tharwat, 1997 and Porter and Cottridge, 2001). Its distribution covers Nile Delta Lakes, Wadi El-Natroun, Alexandria to El- allum, Suez Canal area, El-Faiyum, Wadi El-Rayan (Tharwat, 1997), Upper Egypt, and Sinai maritime littoral (Meinertzhagen, 1930 and Anany, 2004). In autumn, there is a significant influx of migrants, particularly along north coast of Sinai. The few individuals recorded from the southern Western Desert oases suggest a trans-Saharan migration (Goodman et al., 1989). It feeds on insects, worms, molluscs, and crustaceans (Tharwat, 1997 and Anany, 2004). It mostly lives singly, or in pairs (Anany, 2004). 


\subsection{Family: Laridae \\ Larus genei (Breme, 1840) \\ Slender-billed Gull}

It is known from a sight record of three individuals in the shallow waters of Zaranik Protectorate. According to Porter and Cottridge (2001), this bird species breeds in the wetlands of Sinai. They added that it can be quite common in Egypt in winter when migrants from the north reach the Mediterranean coasts. It was reported, however, that this species was rarely seen in Egypt (Meinertzhagen, 1930; Al-Husseini, 1954 and Anany, 2004). It inhabits coastal waters and estuaries, where it feeds on fish and invertebrates (Tharwat, 1997). He added that the distribution of this species covers northwestern Sinai, Lake Qaroun, and the Mediterranean and Red Sea areas. It was also recorded from Qena in Upper Egypt, Suez Canal, Gulf of Suez (Meinertzhagen, 1930).

\section{Order: Strigiformes}

2.5. Family: Strigidae

Athene noctua (Scopoli, 1769)

\section{Little Owl}

A single owl was observed during daytime resting on the top of a pile of limestone beside an asphalt road, very close to Wadi El-Agra area. Little owls of Sinai are referred to the subspecies saharae. According to Porter and Cottridge (2001), the little owl is a fairly common resident in Egypt and is often seen in daylight. It frequents open country with trees, stony wastelands and rocky semi-deserts, nesting in holes in tree and in rocks or buildings, and burrows. The distribution of this subspecies covers Western and Eastern Deserts, Sinai, and Nile Delta and Valley (Tharwat, 1997). This subspecies was also recorded from the Western Mediterranean Coastal Desert (Mersa Matruh and El-Sallum), and Wadi El-Natroun, (AlHusseini, 1954), Cairo-Suez road, Moqattam Hills east of Cairo, and Dakhla Oasis (Meinertzhagen, 1930). The same author added that it was fairly evenly distributed throughout Sinai. In Sinai, it was recorded as far south as Dahab (Goodman et al., 1989). They added that the species bred in the mountains between Qusaima and Elat. It feeds on invertebrates and butterflies, lizards, small rodents and birds (Al-Husseini, 1954; Tharwat, 1997; Porter and Cottridge, 2001and Anany, 2004).

\section{Order: Passeriformes}

2.6.Family: Laniidae

\section{Lanius meridionalis (Linnaeus, 1758)}

\section{Southern Grey Shrike}

It is known from sight records in Wadi El-Agra area. According to Porter and Cottridge (2001), the southern grey shrike was systematically split from the very similar great grey shrike, L. exubitor, of northern Europe. 
It is a fairly common breeding bird in various portions of the country. It inhabits desert areas with small desert shrubs, and is rarely observed in agricultural areas (Al-Husseini, 1954 and Anany, 2004). Meinertzhagen, earlier in 1930, indicated that this species never came into cultivated areas. It has a wide distribution in Egypt that covers Kharga Oasis (Meinertzhagen, 1930), El-Faiyum, Wadi El-Natroun (Al-Husseini, 1954), the North Coast, Nile Delta and Valley, Suez Canal area, northern Eastern Desert and northern Sinai (Tharwat, 1997). The same author, identifying this shrike by its previous name, L. exubitor, adds that it feeds on large insects, small mammals, reptiles, and small birds. In Sinai, the species is a locally common breeding bird in the north between Al Arish and Rafah, and in vegetated wadis in the east and south (Goodman et al., 1989). Bedouins of the area told us that this bird species is in the habit of collecting insects and small reptiles and fixing them to the acute apices of thorny desert plants to feed on them later (Fig. 9). In Wadi El-Agra area, a beetle and a small chameleon were seen fixed by this bird species to the leave apices of a cactus planted by locals in a remote site of the Wadi.

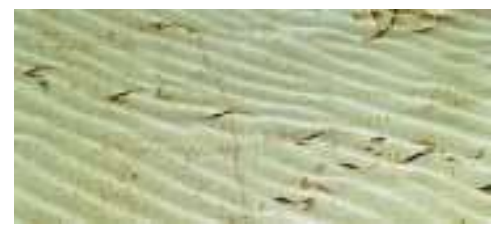

Fig. (7). Tracks of Cerastes vipera observed in Wadi El Agra.

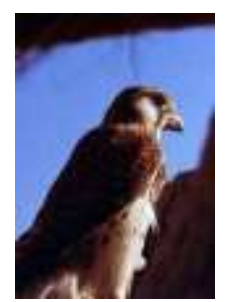

Fig. (8). Common kestrel, Falco tinnunculus held by a local Bedouin in Wadi El Agra.

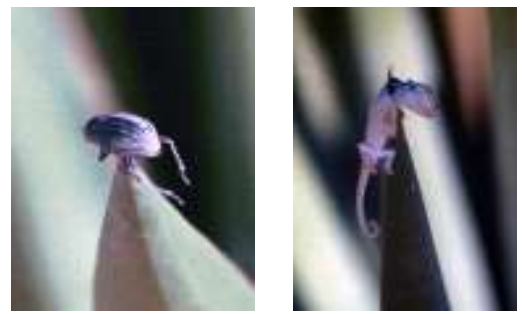

Fig. (9). Food items collected by Lanius meridionalis; a beetle (left) and a small chameleon (right). 
3. Class: Mammalia

Order: Rodentia

3.1. Family: Muridae

Subfamily: Gerbillinae

3.1.1. Gerbillus floweri (Thomas, 1919)

Flower's Gerbil

It was collected from various localities in northeastern Sinai, namely Al-Zaranik area, Al-Dhahir, Wadi El-Agra, Wadi Umm Shehan, Al-Gora, Sadd El-Rawafaa area, Bir Lehfen and Al-Khrafeen. A total of 619 individuals (300 males and 319 females) were collected throughout the study period (Fig. 10). It was the most abundant of all rodent species and subspecies collected from these localities since it formed 51.2\% of the total sample collected during the study period (Mohallal, 2007). This species is confined in distribution to the northern parts of Sinai Peninsula and Eastern Desert. It was collected before from El Arish and other localities in north Sinai (Flower, 1932; Wassif, 1953; Setzer, 1958a; Haim and Tchernov, 1974 and Osborn and Helmy, 1980). It inhabits sand dune areas (Wassif, 1953) and palm groves near cultivations (Hoogstraal, 1963), but it does not exist in the dunes of southern Sinai (Haim and Tchernov, 1974). It penetrates into the Holy Land where it is restricted to sandy areas (Qumsiyeh, 1996). During the course of the present study it was collected from sand dune habitats in Wadi El-Agra as well as from areas of almond and peach trees in the same wadi and in El-Kharafeen area, and from coastal dunes of white sand in Al-Zaranik area.

\subsubsection{Gerbillus gerbillus (Olivier, 1801) \\ Lesser Gerbil}

Thirty five individuals (17 males and 18 females) that belong to the subspecies asyutensis were collected from three localities in northeastern Sinai; namely, Al-Zaranik, Wadi El-Agra, and Sadd El-Rawaf aa area. This subspecies is distributed to Sinai Peninsula and the northern part of the Eastern Desert. It was recorded from various localities throughout northern and southern Sinai (Wassif, 1953; Setzer, 1960; Hoogstraal, 1963; Haim and Tchernov, 1974; Osborn and Helmy, 1980 and Saleh and Basuony, 1998). It inhabits dunes and alluvial fans and sandy valleys and is limited to elevations below 1,100 $\mathrm{m}$ (Haim and Tchernov, 1974). It penetrates into the desert areas of the Holy Land (Qumsiyeh, 1996). 


\subsubsection{Gerbillus andersoni (De Winton, 1902) \\ Aderson's Gerbil}

A total of seven individuals ( 4 males and 3 females) belonging to the subspecies bonhotei was collected from Al-Filosiyat Island of Al-Zarnik area, $35 \mathrm{~km}$ to the west of Al-Arish. Two other specimens of this subspecies were collected from Wadi El-Agra. This subspecies is confined in distribution to northeastern Sinai (Thomas, 1919; Flower, 1932; Wassif, 1953 and Osborn and Helmy, 1980). It inhabits sandy areas of collection localities. Another subspecies, allenbyi, was collected for the first time in Egypt (Soliman and Mohallal, 2006). A total of 14 individuals (7 males and 7 females) were collected from two localities in northeastern Sinai; namely, Al-Dhahir and Wadi El-Agra (Fig. 11). Two other specimens of this subspecies were collected from Al-Matly Island of Al-Zaranik area. The majority of specimens of G. andersoni collected from Abu Egerem, AlDhahir, and Wadi El-Agra in northeastern Sinai showed intergradations of color between bonhotei and allenbyi. It seems that possible interbreeding between these two subspecies has taken place.

\subsubsection{Dipodillus dasyurus (Wagner, 1842) Wagner's Dipodil}

Only two males were collected from a gravelly plain in Wadi Umm Shehan. It is distributed to the northern part of the Eastern Desert and Sinai Peninsula, where it was recorded from different localities in its northern and southern parts (Flower, 1932; Wassif and Hoogstraal, 1953; Wassif, 1956; Setzer, 1958a and Osborn and Helmy, 1980). It inhabits sandy valleys (Hoogstraal, 1963), and is common in arid rocky areas of north and central Sinai (Haim and Tchernov, 1974). It penetrates into the Holy Land, where it is present throughout the country in all habitats ranging from the Mediterranean mountainous regions to the arid Negev and Syrian deserts (Qumsiyeh, 1996).

\subsubsection{Dipodillus henleyi (De Winton, 1903) Pigmy Dipodil (A new collection locality)}

Three individuals ( 2 males and 1 female) were collected from three localities; namely, Wadi Umm Shehan, which is characterized by its gravelly habitat, Bir Lehfen, in a moderately vegetated site, and Wadi El-Agra area in sand dunes and wadis of soft sand and moderate vegetation. It is represented in Sinai Peninsula and the Eastern Desert by the subspecies mariae. The habitat of this species is not yet well defined because of its sporadic captures, perhaps due to its small size (Haim and Tchernov, 1974). The present collection localities represent new ones for this subspecies in Sinai Peninsula, since it was collected before only in southwest Sinai (Osborn and 
Helmy, 1980). It was collected from sparsely and moderately vegetated wadis, and gravelly habitats. Specimens of Gebel El Maghara were collected in a valley filled with gravel stones with Retama raetam and Anabasis syriaca (Haim and Tchernov, 1974). It penetrates into the Holy Land where it is confined to arid regions including the Negev (Qumsiyeh, 1996).

\subsubsection{Meriones crassus (Sundevall, 1842)}

\section{Sundevall's Jird - Silky Jird}

Eleven individuals ( 7 males and 4 females) were collected from four localities in northeastern Sinai; namely Wadi Umm Shehan, Wadi El-Agra, Bir Lehfen and Al-Quore'aa, which is very close to Bir Lehfen. It is represented in Sinai by the subspecies crassus, which exists throughout Sinai and the Eastern Desert in littoral deserts bordering the Mediterranean and Red Seas. It is also present near St. Catherine Monastery, up to latitudes of 1,500 meters, where it is always associated with desert shrubs (Hoogstraal, 1963 and Haim and Tchernov, 1974). It was recorded from various localities in north Sinai (Flower, 1932; Setzer, 1961 and Osborn and Helmy, 1980). This species is found in concentrated groups around garbage dumps, and inhabits valleys, plains and dunes (Haim and Tohernov, 1974). Burrows may be found in barren, stony, gravelly, or mud terraces, and around or beneath buildings and tents (Briscoe, 1956). Haim and Tchernov (1974) regularly found seeds of Zygophyllum spinosa, and seeds and stalks of Anabasis articulata near its burrow opening. It penetrates into the Holy Land, where it is common in arid southern and eastern regions (Qumsiyeh, 1996).

\subsubsection{Meriones sacramenti (Thomas, 1922) \\ Negev Jird}

A total of 38 individuals (14 males and 24 females) was collected throughout the study period from three localities, namely; Wadi Umm Shehan, Al-Gora, and Wadi El-Agra (Fig. 12). The multientranced burrows of this jird were observed in Wadi El-Agra beside watermelon plantations, and the trees of peach, almond and pomegranate. It was recorded from Bir Lehfan (Wassif, 1953), and Rafah (Osborn and Helmy, 1980). It is a colonial jird as Wahrman and Zahavi (1955) suggested, and is a probable pest of crops. It caused serious injuries to watermelon plantations in Wadi El-Agra (Fig. 13). It is endemic to the Negev and the coastal region of northern Sinai and the Holy Land (Qumsiyeh, 1996). 


\subsubsection{Meriones tristrami (Thomas, 1892) \\ Tristram's Jird}

Only one specimen was collected from Wadi El-Agra in northeastern Sinai, in areas of loose sand and moderate vegetation. The collected specimen was found dead and injured by ants, so that it was not possible to take accurate body measurements. It is known in Egypt from specimens collected from Al-Arish by Zahvi and Wahrman (1957). According to these authors, the jird lives in sandy areas along the Mediterranean coast, and in alluvial and clay soils. The specimen collected in the present study is the first to be collected after those of Zahavi and Wahrman (1957). The distribution of this jird in the Holy Land seems to be influenced by rainfall. It is thus limited to areas receiving more than $100 \mathrm{~mm}$ of rainfall annually, with the exception of desert habitats in northeastern Jordan and east Syria (Qumsiyeh, 1996). It can become a pest in some areas of Palestine (Zahavi and Wahrman, 1957).

\subsubsection{Psammomys obesus (Thomas, 1902) \\ Fat Sand-rat}

Only one individual was collected from Al-Filosiyat Island of AlZaranik Protected area by the rangers of the protectorate, who allowed the authors of the present study to examine the specimen. It was found in one of the pitfall traps used for monitoring reptiles. The fat sand-rat of Sinai is referred to the subspecies terraesanctae, which is the smallest and palest subspecies of fat sand-rats in Egypt. It is distributed to the northern and southern parts of Sinai Peninsula, and the northern part of the Eastern Desert, where it lives in colonies in sandy and marshy biotope. It was recorded from different localities in north Sinai (Flower, 1932; Wassif, 1953; Hoogstraal, 1963; Haim and Tchernov, 1974 and Osborn and Helmy, 1980). $P$. obesus inhabits saline soils and salt marshes with stands of succulent halophytic vegetation chiefly of family Chenopodiaceae. It was found in a low dune area near Al-Arish (Hoogstraal, 1963). It burrows in sand mounds accumulated around shrubs of Anabasis articulata (Wassif, 1953).

\section{Subfamily: Murinae}

\subsubsection{Mus musculus (Brants, 1827)}

\section{House Mouse}

A total of 10 individuals (5 males and 5 females) was collected from four localities; namely, Al-Arish, Abu-Egerem, Al-Khrafeen, and Wadi Umm Shehan. It was collected in peach and almond orchards in AlKharafeen area, in gravelly plains in Wadi Umm Shehan, and in coastal vegetated sand dunes in Abu Egerem. The collection sites were few meters from human settlements and Bedouin tents. It was also trapped inside a 
house in Al-Arish city. The species was recorded before from different localities in Sinai Peninsula (Wassif, 1953 and Osborn and Helmy, 1980).

\subsection{Family: Dipodidae \\ Jaculus jaculus (Linnaeus, 1758) \\ Lesser Jerboa}

A total of 88 individuals (48 males and 40 females) of Jaculus jaculus was collected from three localities; namely, Al-Dhahir, Al-Gora, and Wadi El-Agra. The characters of the present sample did not conform to the corresponding ones of $J . j$. schlueteri (Nehring, 1901) collected from the northern part of the Eastern Desert and Sinai Peninsula (Flower, 1932; Wassif, 1953; Setzer, 1958b and Osborn and Helmy, 1980). The specimens collected rather belong to a new subspecies proposed by Soliman and Mohallal (2006); namely, J. j. longipodus (Fig. 14). Lesser jerboas burrow in loose sand hills and hillocks (Wassif, 1953). Haim and Tchernov (1974) added that $J$. jaculus inhabits big sandy valleys, sandy plateaus as well as rocky areas of North and South Sinai.

\section{Order: Carnivora}

\subsection{Family: Canidae \\ Vulpes vulpes (Linnaeus, 1758) \\ Red Fox}

A live specimen collected from Wadi El-Agra area was delivered to us by a local Bedouin. The Red Fox is widely distributed in Egypt, and was recorded before from various localities in Sinai (Anderson, 1902 and Flower, 1932), but it was not recorded from Sinai by later authors (Wassif, 1953; Wassif and Hoogstraal, 1953; Hoogstraal, 1963 and Osborn and Helmy, 1980). In 1998, Saleh and Basuony collected eleven specimens of this fox from various localities of Sinai and referred these specimens to the subspecies arabica. According to Hoath (2003), this fox seems to be expanding along the roads, following the spread of human activity and urban development. The same author added that the Red Fox had invaded Sinai as far south as Ras Mohammed.

\subsection{Family: Mustelidae}

\subsubsection{Vormela peregusna (Güldenstädt, 1770)}

\section{Marbled Polecat}

Only one specimen was collected from Wadi El-Agra (Fig. 15). The tracks of the animal were also observed throughout the wadi. Two dead specimens from unknown locality in Sinai were delivered, after the end of this survey, by animal collectors. The marbled polecat was first added to the list of Egyptian mammals by Saleh and Basuony (1998). They collected a live specimen and a fragmented skull, and obtained a skull and a mounted 
skin from various localities in North Sinai. They also observed the tracks of the animal in sandy habitats throughout this region. They indicated that the species was well known to local Bedouins and appeared to be common throughout northern Sinai, and referred collected specimens to the subspecies syriaca. The species is widely distributed in the northern Arabian Peninsula to southeastern Europe and East to western China. The marbled polecat weighs less than $0.5 \mathrm{~kg}$, and like many mustelids, produces an offensive smell. The striking and beautiful coloration may act as a warning for other animals (Qumsiyeh, 1996).

\subsubsection{Meles meles (Linnaeus, 1798) Common Badger}

It was first recorded from northern Sinai by Soliman (2006). Bones of the animal, including the skull together with a bunch of hair were delivered to this author in winter 2004 by a local Bedouin. It was collected from "Sayalat Al-Bawaty" area, about $30 \mathrm{~km}$ to the south of the Mediterranean seashore and about $15 \mathrm{~km}$ to the west of the eastern frontiers of Egypt. According to the same author, it seemed that the animal had been killed by locals since it had the left frontal bone severely damaged. The bones were completely free of soft tissues; an indication that the animal was dead long time ago. The species is widely distributed throughout many countries such as Syria, Iraq and the Mediterranean areas of Lebanon and the Holy Land (Harrison and Bates, 1991). The common badger is readily distinguished among the Arabian mustelids by its large size and heavy built, since adult females weigh $5-10 \mathrm{~kg}$ and adult males weigh 7-14 kg. Soliman (2006) referred the collected specimen to the subspecies canescens on the basis of the shape of the first upper molar. A live specimen was later recorded near Ain El Godyrat in northeastern Sinai (Saleh and Basuony, 2014). In Lebanon, badgers live near cultivated areas and build extensive burrow systems to depths of one meter or more. The animal is primarily nocturnal and feeds on rodents, reptiles, and insects with some intake of plant material such as fruits and buds (Lewis et al., 1968 and Qumsiyeh, 1996). Badgers can damage crops and are known to carry bovine tuberculosis.

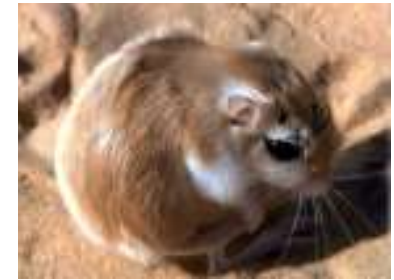

Fig. (10). Gerbillus floweri

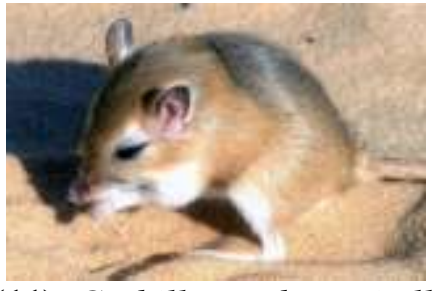

Fig. (11). Gerbillus andersoni allenbyi 


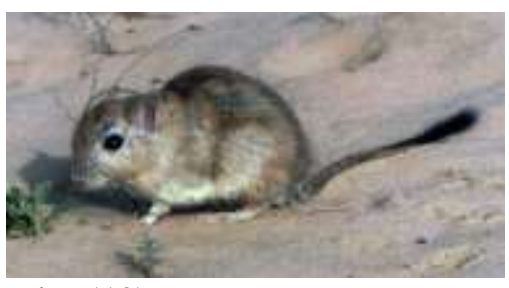

Fig. (12). Meriones sacramenti

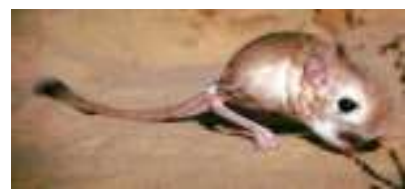

Fig. (14). Jaculus jaculus longipodus

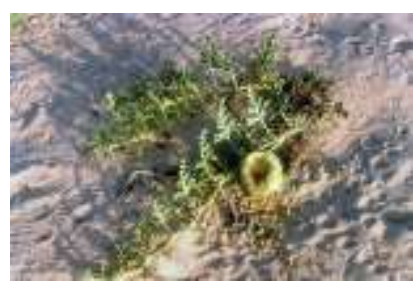

Fig. (13). Watermelon plantations are severely damaged by Meriones sacramenti in Wadi El-Agra.

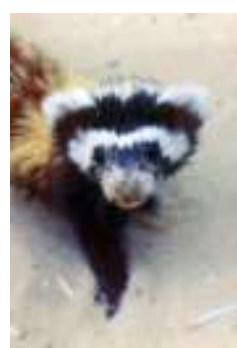

Fig. (15). Vormela peregusna

\section{Order: Artiodactyla}

3.5. Family: Bovidae

Gazella gazella (Pallas, 1766)

\section{Arabian Gazelle}

Few individuals of this gazelle as well as gazelle foot tracks and fecal droppings were observed in areas adjacent to Wadi El-Agra. A fragment of a skull covered with skin, with one horn removed, together with a leg shaft with hoofs, all belonging to a recently killed gazelle, were delivered to us by one of the Bedouins of the wadi. The annulated long horn indicates that it belongs to a male gazelle. Women of the area use horns of killed gazelles in weaving woolen rugs; one of the famous handcraft products of Sinai. It is characterized by the presence of a small blackish tuft at the base of the hoofs anteriorly. The hoofs are also long, narrow and pointed anteriorly, and the marginal fringes of the ear are pure white (Harrison and Bates, 1991). The ear length of the delivered specimen is 117 $\mathrm{mm}$ and the hoof length is $65 \mathrm{~mm}$. G. gazella was sight recorded by Flower (1932) from Sinai, including Wadi Al Arish in North Siani. It lives in coastal plains, foothills, and mountains of the Arabian Peninsula, and is absent from the interior steppe and desert. 


\section{REFERENCES}

Abu Al-Izz, M. A. (1971). In "Landforms of Egypt". American University Press, Cairo, $\mathrm{xv}+281 \mathrm{pp}$.

Al-Husseini, A. H. (1954). In "Birds of Egypt: with A Brief Consideration of Bird Life". Anglo-Egyptian Bookshop, 372 pp. (In Arabic).

Anany, M.M. (2004). In "Egypt Birds". Maktabat Al-Osra, Scientific Works, Book Authority, Egypt, 348 pp. (In Arabic).

Anderson, J. (1898). In "Zoology of Egypt: I. Reptilia and Batrachia". Bernard Quaritch, London.

Anderson, J. (1902). In "Zoology of Egypt: Mammalia". Revised and completed by W.E. De Winton. Hugh Rees Ltd., London, xvii + 374 pp.

Baha El Din, S. (2006). In "A Guide to the Reptiles and Amphibians of Egypt". The American University in Cairo Press, Cairo-New York, $\mathrm{xi}+359$ pp.+127 colored figures.

Bennett, D. (1995). In "A Little Book of Monitor Lizards". Viper Press, Aberdeen, 208 pp.

Briscoe, M.S. (1956). Kinds and distribution of wild rodents and their ectoparasites in Egypt. Amer. Midl. Nat., 55 (2): 393-408.

Flower, S.S. (1932). Notes on the recent mammals of Egypt, with a list of the species recorded from the kingdom. Proc. Zool. Soc., London, 1932: 368-450.

Goodman, S.M., P.L. Meininger, S.M. Baha El Din, O.J. Hobbs and W.C. Mullié (1989). In "The Birds of Egypt". Oxford University Press, New York, xxi+551 pp.

Haim, A. and E. Tchernov (1974). The distribution of myomorph rodents in the Sinai Peninsula. Mammalia, 38: 201-223.

Harrison, D.L. and P.J.J. Bates (1991). In "The Mammals of Arabia". Harrison Zoological Museum Publication, vi + 354 pp.

Hoath, R. (2003). In "Field Guide to the Mammals of Egypt". The American University in Cairo Press, Cairo- New York, $x v+236$ pp.

Hoogstraal, H. (1963). A brief review of the contemporary land mammals of Egypt (including Sinai), 2: Lagomorpha and Rodentia. J. Egypt. Publ. Health Assn., 38: 1-35.

Lewis, R.E., J.H. Lewis and S.I. Atallah (1968). A review of Lebanese mammals, Carnivora, Pinnipedia, Hyracoidea and Artiodactyla. J. Zool. (Lond.) 15: 517-531.

Marx, H. (1968). In "Checklist of the Reptiles and Amphibians of Egypt". Special Publication, US-NAMRU-3, Cairo, Egypt, iii + 91 pp.

Meinertzhagen, R. (1930). In "Nicoll's Birds of Egypt". Hugh Rees Ltd, London, xvi+700 pp. (2 volumes). 
Mohallal, E.M. (2007). Ecological and taxonomic studies on rodent populations inhabiting Sinai Peninsula and the Eastern Desert of Egypt. M.Sc. Thesis, Ain Shams Univ., Cairo, Egypt.

Osborn, D. J. and I. Helmy (1980). In "The Contemporary Land Mammals of Egypt (Including Sinai)". Fieldiana Zoology, Field Museum of Natural History, New Series, 5: xix + 579 pp.

Porter, R. and D. Cottridge (2001). In "A photographic Guide to Birds of Egypt and the Middle East". The American University in Cairo Press, Cairo- New York, 144 pp.

Qumsiyeh, M.B. (1996). In "Mammals of the Holy Land". Texas Tech University Press, $\mathrm{x}+389 \mathrm{pp}$.

Saleh, M.A. (1997). In "Amphibians and Reptiles of Egypt". Egyptian Environmental Affairs Agency, Publications of the National Biodiversity Unit, No. 6, viii +234 pp.

Saleh, M.A. and M.I. Basuony (1998). A contribution to the mammalogy of the Sinai Peninsula. Mammalia, 62 (4): 557-575.

Saleh, M.A. and M.I. Basuony (2014). New mammalian records from Egypt. Egypt. J. Zool., 62:111-130.

Setzer, H.W. (1958a). The gerbils of Egypt. J. Egypt. Publ. Hlth. Assn., 33: 205-227.

Setzer, H.W. (1958b). The jerboas of Egypt. J. Egypt. Publ. Hlth. Assn., 33: 87-94.

Setzer, H.W. (1960). Two new mammals from Egypt. J. Egypt. Publ. Hlth. Assn., 35: 1-5.

Setzer, H.W. (1961). The jirds (Mammalia: Rodentia) of Egypt. J. Egypt. Publ. Hlth. Assn., 36: 81-92.

Soliman, S. (2006). The Common Badger, Meles meles, (Linnaeus, 1758) (Carnivora, Mustelidae): a new record from northeastern Sinai, Egypt. Egypt. J. Zool., 47: 221-225.

Soliman, S. and E.M. Mohallal (2006). Jaculus j. longipodus ssp. nov. (Rodentia, Dipodidae), a new subspecies, and Gerbillus andersoni allenbyi (Thomas, 1918) (Rodentia, Cricetidae), a new record, from Northeastern Sinai, Egypt. Egypt. J. Zool., 47.

Tharwat, M.E. (1997). In "Birds Known to Occur in Egypt". Egyptian Environmental Affairs Agency, Publications of the National Biodiversity Unit, No. 8, vi +204 pp. +20 colored plates +3 indices.

Thomas, O. (1919). Two new gerbils from Sinai. Ann. Mag. Nat. Hist., (ser. 9), 3: 559-560.

Wahrman, J. and Z. Zahavi (1955). Cytological contributions to the phylogeny and classification of the rodent genus Gerbillus. Nature, 175: 600-602.

Wassif, K. (1953). On a collection of mammals from Northern Sinai. Bull. Inst. Désert Egypte, 3: 107-118. 
Wassif, K. (1956). Studies on gerbils of the subgenus Dipodillus recorded from Egypt. Ain Shams Sci. Bull., 1: 173-199.

Wassif, K. and H. Hoogstraal (1953). The mammals of south Sinai, Egypt. Proc. Egypt. Acad. Sci., 9: 63-79.

Zahavi, A. and J. Wahrman (1957). The cytotaxonomy, ecology, and evolution of the gerbils and jirds of Israel (Rodentia-Gerbillinae). Mammalia, 21: 341-380.

Received: $10 / 6 / 2016$

Accepted: 11/8/2016

Egyptian J. Desert Res., 66, No. 1, 35-55 (2016) 


\section{الفونا الفقارية المسجلة من شمال شرق سيناء، مصر}

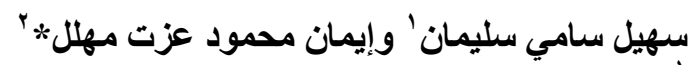

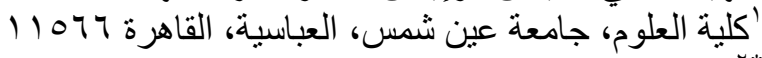

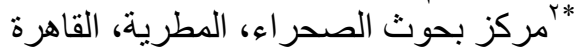

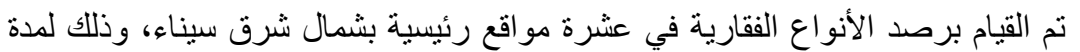

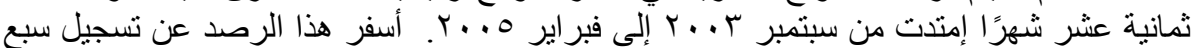

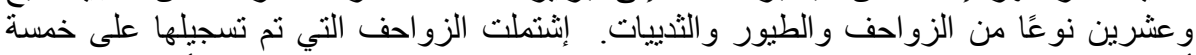

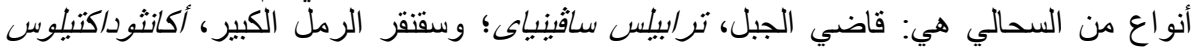

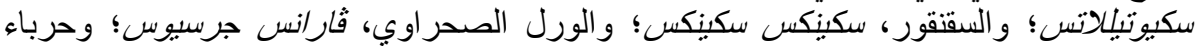

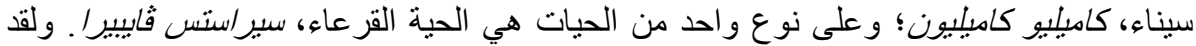

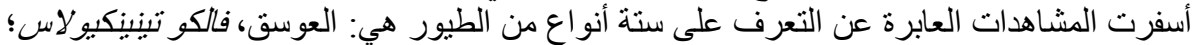

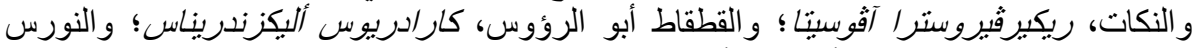

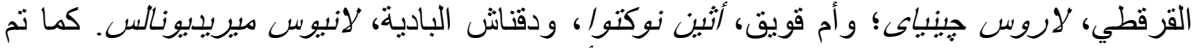

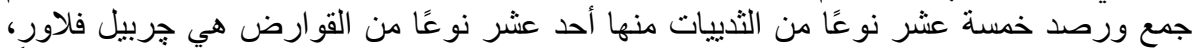

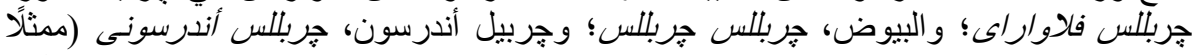

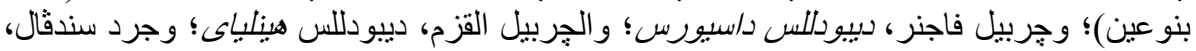

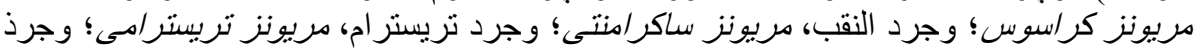

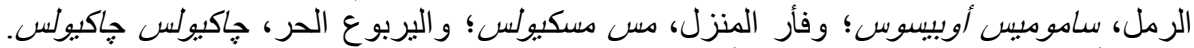

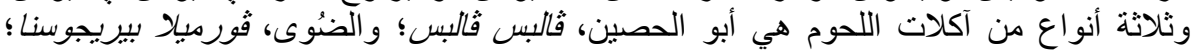

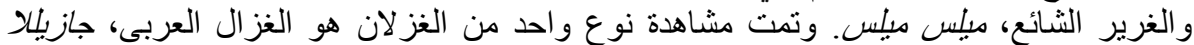

